\title{
Cytogenetic study of two species of the family Pimelodidae (Siluriformes) collected in lago Guaíba, Rio Grande do Sul, Brazil
}

\author{
Fernando Rodrigo Treco', Luiz R. Malabarba², \\ Lucia Giuliano-Caetano ${ }^{1}$ and Ana Lúcia Dias ${ }^{1}$
}

\begin{abstract}
A cytogenetic study was conducted on specimens of Parapimelodus nigribarbis and Pimelodus maculatus collected in the lago Guaíba drainage, Porto Alegre, Rio Grande do Sul, Brazil. The two species had a diploid number of 56 chromosomes, with P. nigribarbis showing a karyotype of $20 \mathrm{~m}+20 \mathrm{sm}+4 \mathrm{st}+12$ a with FN of 100 , and P. maculatus showing a karyotype of $24 \mathrm{~m}+$ $20 \mathrm{sm}+6 \mathrm{st}+6 \mathrm{a}$ with FN of 106 . NORs were demonstrated in both species in only one pair of subtelocentric chromosomes, in the terminal region of the long arm, which was coincident with $\mathrm{C}$ - banding and $\mathrm{CMA}_{3}$ staining, while DAPI staining was negative in these regions. Parapimelodus nigribarbis had a greater number of heterochromatic bands than did $P$. maculatus, which were distributed mainly in the terminal regions, where the latter species showed an interstitial band on the short arm of the first metacentric pair. C-banding plus $\mathrm{CMA}_{3}$ demonstrated heterochromatin that was associated with GC-rich NORs in both P. nigribarbis and P. maculatus, although other fluorescent regions were also observed in the former species. With C-banding plus DAPI, various chromosomal regions were stained in the two species, along with interstitial staining in P. maculatus, indicating that heterochromatin contained a greater quantity of AT-rich regions.
\end{abstract}

Exemplares de Parapimelodus nigribarbis e Pimelodus maculatus coletados na bacia do rio Guaíba, Porto Alegre, Rio Grande do Sul, foram analisados citogeneticamente. As duas espécies apresentaram um número diplóide de 56 cromossomos, com $P$. nigribarbis mostrando um cariótipo de $20 \mathrm{~m}+20 \mathrm{sm}+4 \mathrm{st}+12 \mathrm{a}$, NF igual a 100 ; e P. maculatus com $24 \mathrm{~m}+20 \mathrm{sm}+6 \mathrm{st}+6 \mathrm{a}$ e NF igual 106. As NORs foram evidenciadas em apenas um par de cromossomos subtelocêntricos, na região terminal do braço longo, nas duas espécies estudadas, sendo coincidentes com a banda $\mathrm{C}$ e CMA; ; o DAPI nestas regiões se mostrou negativo. Parapimelodus nigribarbis apresentou um maior número de bandas heterocromáticas do que $P$. maculatus, distribuídas principalmente em regiões terminais, sendo observada nesta última espécie uma banda intersticial no braço curto do primeiro par metacêntrico. Banda $\mathrm{C}+\mathrm{CMA}_{3}$ evidenciou em $P$. nigribarbis e $P$. maculatus a heterocromatina associada à NOR rica em GC, sendo encontrada na primeira espécie outras regiões fluorescentes. Com banda C + DAPI várias regiões cromossômicas foram observadas nas duas espécies, inclusive a porção intersticial encontrada em P. maculatus, revelando que a heterocromatina possui uma maior quantidade de regiões AT ricas em sua composição.

Key words: Parapimelodus, Pimelodus, NOR, Heterochromatin, Fluorochromes.

\section{Introduction}

The family Pimelodidae is an extremely diversified group composed of approximately 93 species distributed among 29 genera (Ferraris, 2007), where they are represented in all the laguna dos Patos drainage by only two species, Parapimelodus nigribarbis and Pimelodus maculatus.

The genus Pimelodus is the most numerous within the family Pimelodidae, composed of 24 species (Ferraris, 2007), and is one of the most studied from a cytogenetic point of view. On the other hand, Parapimelodus is represented by only two species, P. valenciennis and P. nigribarbis.

Among the species belonging to the genus Pimelodus, $P$. maculatus is the one that has been cytogenetically most studied by various authors (Vissoto et al., 1999; Swarça et al., 2001a; Borin \& Martins-Santos, 2002; among others). The different samples examined showed a diploid number of 56 and variations in their karyotype formula, along with simple NORs and heterochromatin distributed mainly in the centromeric and/or terminal regions.

${ }^{1}$ Universidade Estadual de Londrina, Departamento de Biologia Geral, 86051-970 Londrina, PR, Brazil.

${ }^{2}$ Universidade Federal do Rio Grande do Sul, Instituto de Biociências, Departamento de Zoologia, Porto Alegre, RS, Brazil. 
With regard to the genus Parapimelodus, only unpublished data from Costa \& Reggi (pers. comm.) could be found, who characterized " $P$. valenciennis" obtained from the "Rio Guaiba" as having a diploid number of $2 \mathrm{n}=56$ chromosomes. The species examined by Costa \& Reggi (pers. comm.), however, was $P$. nigribarbis, the same species studied in the present study. Parapimelodus nigribarbis, originally described for the laguna dos Patos system, was treated as a synonym of $P$. valenciennes, described for the rio da Prata basin until 1992, when it was considered a valid species and removed from synonymy with the latter by Lucena et al. (1992). Parapimelodus nigribarbis is endemic to the area and is the only species of the genus present in the laguna dos Patos system.

The aim of the present study was to characterize and compare cytogenetically two species of the family Pimelodidae, Parapimelodus nigribarbis and Pimelodus maculatus, from lago Guaiba, laguna dos Patos drainage, Rio Grande do Sul. The findings for Pimelodus maculatus were further compared to cytogenetic data for specimens from other parts of South America.

\section{Materials and Methods}

Thirteen specimens of Parapimelodus nigribarbis (6 males and 7 females) and five specimens of Pimelodus maculatus ( 2 males, 1 female and 2 unsexed), were collected in lago Guaíba, Porto Alegre, Rio Grande do Sul. The specimens examined were deposited in the Museu de Zoologia da Universidade Estadual de Londrina: MZUEL 4060 - Parapimelodus nigribarbis; MZUEL 4061, MZUEL 4062 and MZUEL 4063 - Pimelodus maculatus.

Mitotic chromosome preparations were obtained from kidney according Bertollo et al. (1978). Chromosome morphology was determined on the basis of arm ratio (Levan et al., 1964). Chromosomes classified as metacentric (m), submetacentric (sm) and subtelocentric (st) were considered as biarmed, and acrocentric (a) were considered as uniarmed. Nucleolar organizer region staining (Ag-NOR) and C- banding were performed using the methods of Howell and Black (1980) and Sumner (1972), respectively. Chromomycin $A_{3}$ $\left(\mathrm{CMA}_{3}\right)$ and DAPI staining were done according to Schweizer (1976).

\section{Results}

The results obtained for the two species reveals a diploid number of $2 \mathrm{n}=56$ chromosomes, where Parapimelodus nigribarbis showed $20 \mathrm{~m}+20 \mathrm{sm}+4 \mathrm{st}+12 \mathrm{a}$ chromosomes with FN $=100$ (Fig. 1a) and Pimelodus maculatus $24 \mathrm{~m}+20 \mathrm{sm}$ $+6 \mathrm{st}+6 \mathrm{a}$ chromosomes with FN=106 (Fig. 1c). The presence of a secondary constriction was noted in the terminal region of the long arm of a pair of subtelocentric chromosomes, pair 24, in P. maculatus (Fig. 1c).

Parapimelodus nigribarbis showed heterochromatin distributed in the centromeric and mainly terminal regions of

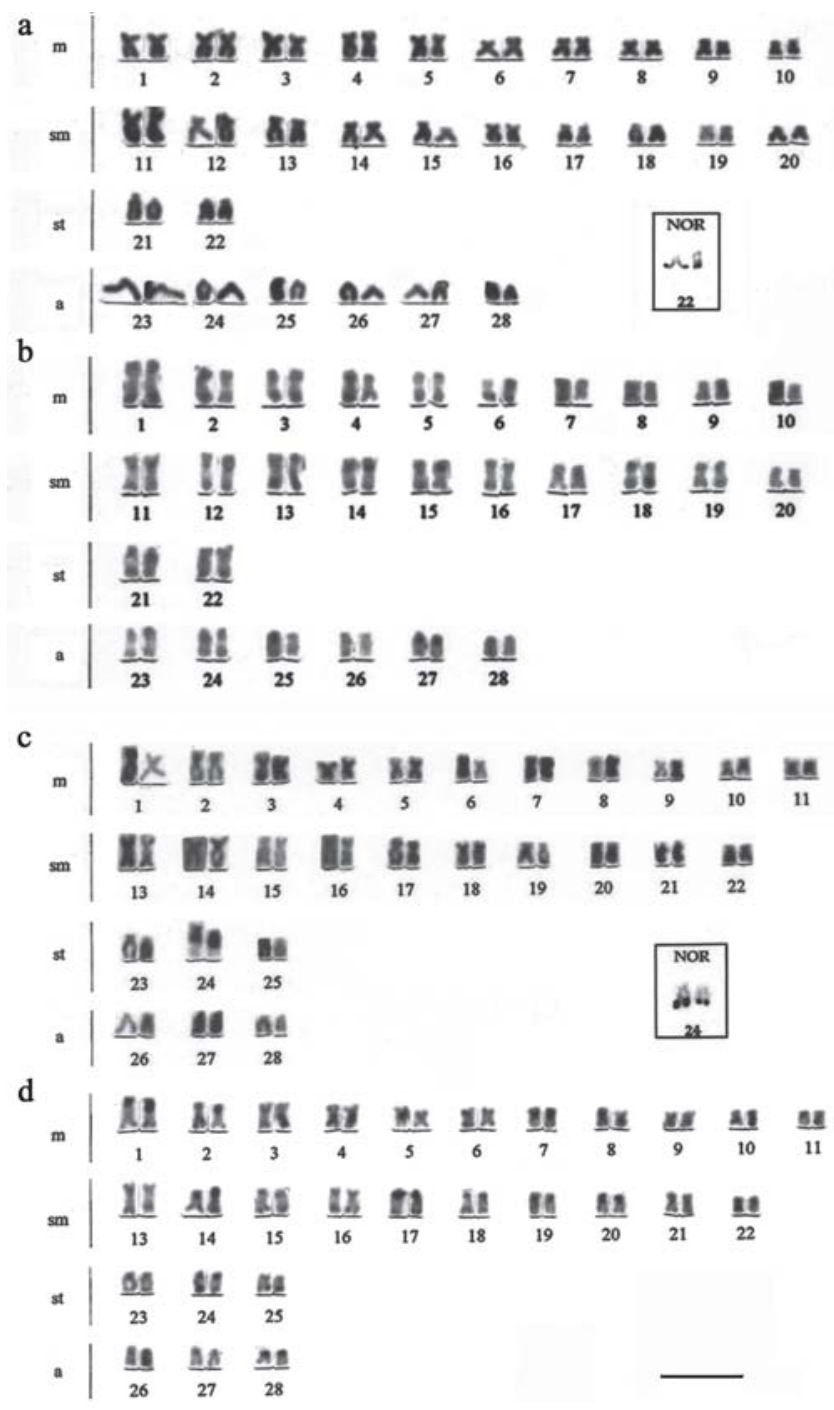

Fig. 1. Karyotype of Parapimelodus nigribarbis (a, b) and Pimelodus maculatus (c, d) with Giemsa (a, c) and C-banding (b, d). In the boxes the Ag-NOR-bearing pair of chromosomes. Scale bar $=10 \mu \mathrm{m}$.

various chromosomes, where heterochromatic staining in metacentric pairs 1, 3, 4 and 5 and submetacentric pairs 13, 15, 18 and 19 was noted at both ends (Fig. 1b). Pimelodus maculatus showed a lesser quantity of heterochromatin, distributed in the centromeric and terminal regions of some chromosomes, with some heterochromatin identified at an interstitial position on the short arm of chromosome pair 1 (Fig. 1d).

Pair 22 of Parapimelodus nigribarbis and pair 24 of Pimelodus maculatus showed heterochromatin in the terminal region of the long arm, where a size heteromorphism was observed in the latter species (Figs. 1b and 1d, respectively).

The Ag-NORs were localized in the terminal region of the long arm in a pair of subtelocentric chromosomes in both species: pair 22 in Parapimelodus nigribarbis (Fig. 1a - box) and pair 24 in Pimelodus maculatus (Fig. 1c - box), where a size heteromorphism was observed between the homologues 

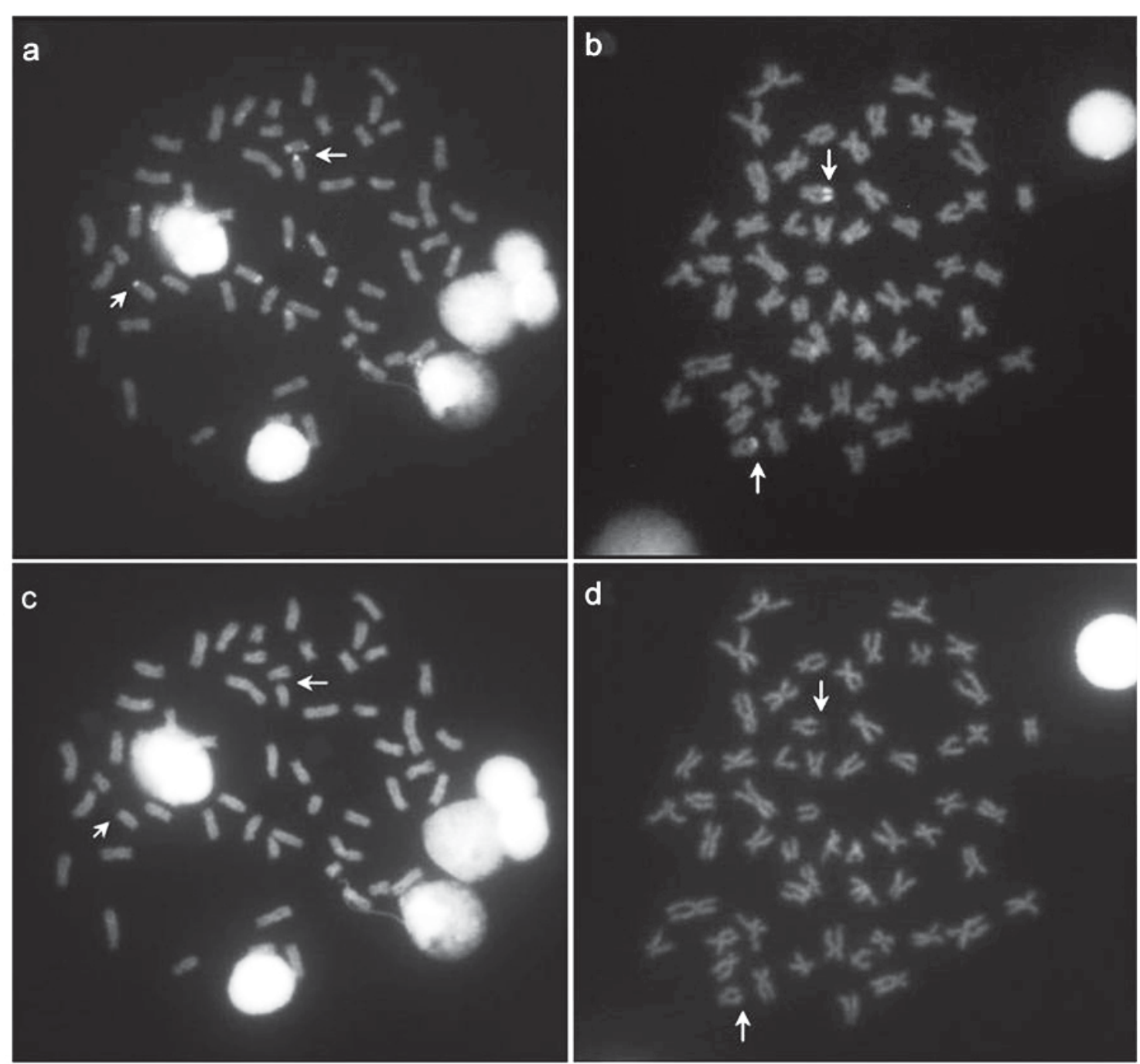

Fig. 2. Somatic metaphases of Parapimelodus nigribarbis: (a) $\mathrm{CMA}_{3}$ and (c) DAPI; Pimelodus maculatus: (b) CMA and (d) DAPI. The arrows indicate the Ag-NOR-bearing pair of chromosomes.

in the latter species.

Staining with the $\mathrm{CMA}_{3}$ produced fluorescent signals corresponding to Ag-NORs in both species (Figs. 2a,b), while additional fluorescent signals were identified in the centromeric and telomeric regions of some chromosomes of Parapimelodus nigribarbis (Fig. 2a)

Staining with the DAPI revealed only pale regions (DAPInegative) which corresponded to $\mathrm{CMA}_{3}$-positive regions, in the two species studied (Figs. 2c,d).

When C-banding was combined with $\mathrm{CMA}_{3}\left(\mathrm{CB}+\mathrm{CMA}_{3}\right)$, stained regions in both species corresponded to Ag-NORs (Figs. 3a,b), while in Parapimelodus nigribarbis other fluorescent signals were seen in the terminal regions of some chromosomes (Fig. 3a).

When C-banding was combined with DAPI (CB + DAPI), various fluorescent bands were identified in the centromeric and terminal regions of various chromosomes in the two species (Figs. 3c,d); in Pimelodus maculatus, the heterochromatin at the interstitial position of metacentric chromosome 1 also showed a fluorescent signal (Fig. 3d).

\section{Discussion}

The present work describes the first detailed cytogenetic study of the genus Parapimelodus, since only its diploid number has been previously reported (Costa \& Reggi, pers. comm.). The diploid number of 56 chromosomes described here for Parapimelodus nigribarbis and Pimelodus maculatus from lago Guaíba, has been found for the majority of the species belonging to the family Pimelodidae. Only 5 of the 32 species whose karyotype was described had a different diploid number: Calophysus macropterus (Gil et al., 1998: $2 \mathrm{n}=50$ ), Pinirampus pirinampu (Swarça et al., 1999: $2 \mathrm{n}=50$ ), Pimelodus fur (Garcia \& Moreira-Filho, 2005: 2n= 54), Megalonema platanum (Sanchez, 2006: 2n= 54), and Pimelodus blochii (Della-Rosa et al., 1980: 2n=58).

Oliveira \& Gosztonyi (2000) suggested that $2 n=56$ chromosomes is the ancestral diploid number of the Siluriformes, which would explain the high frequency of this number in this family. Therefore, this diploid number can be considered a plesiomorphic trait in the family Pimelodidae and in the ge- 

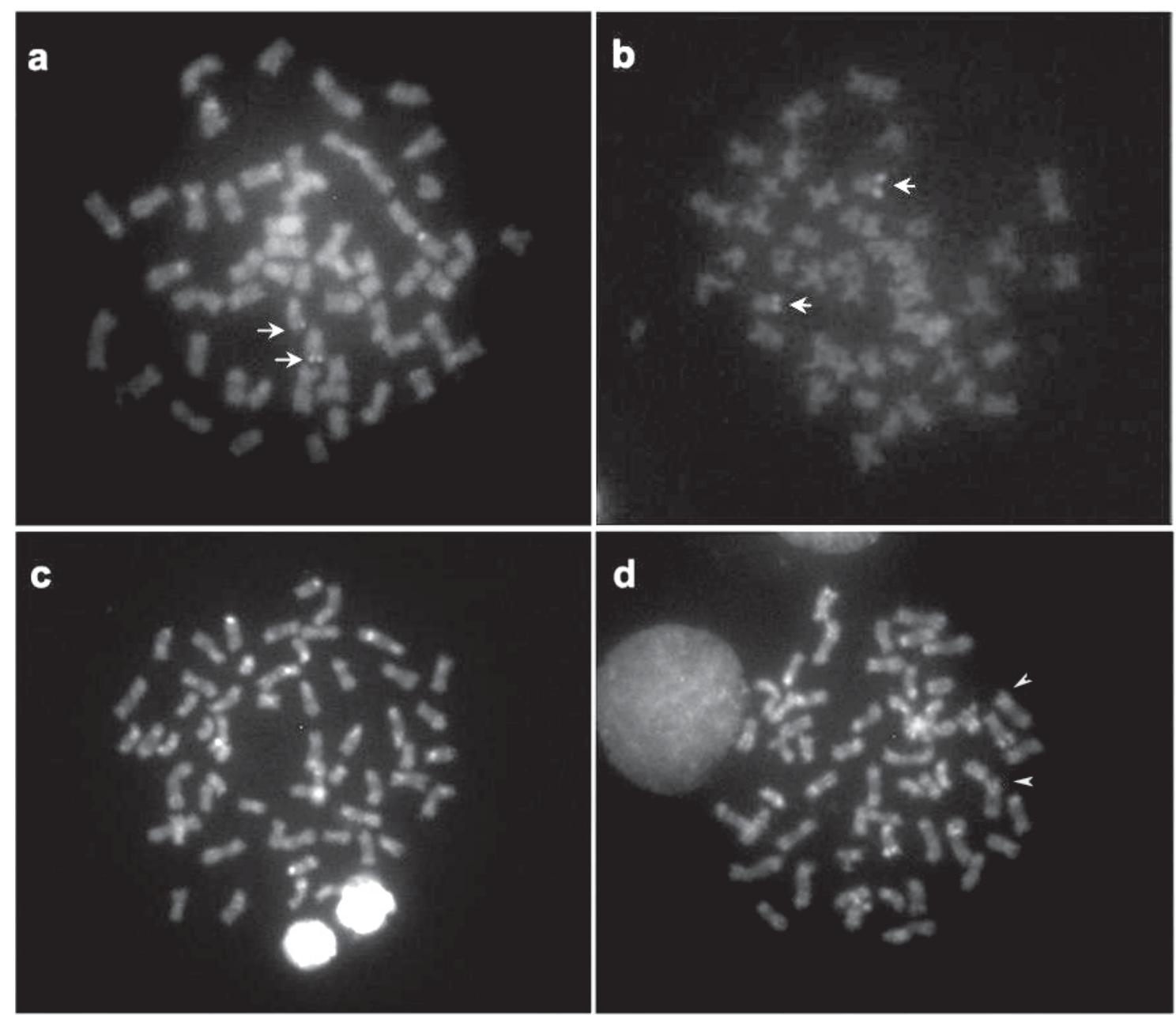

Fig. 3. Somatic metaphases of Parapimelodus nigribarbis: a) $\mathrm{CB}+\mathrm{CMA}_{3}$ and c) $\mathrm{CB}+\mathrm{DAPI}$; Pimelodus maculatus: b) $\mathrm{CB}+\mathrm{CMA}$ and d) CB+DAPI. The arrows indicate the NOR-bearing pair of chromosomes. The arrowheads in (d) indicate the chromosome pair 1 .

nus Pimelodus, where the majority of their species also have $2 \mathrm{n}=56$ chromosomes (Swarça et al., 2001a; Borin \& MartinsSantos, 2002, 2004; Garcia \& Moreira-Filho, 2005; among others).

Among the eleven samples of Pimelodus maculatus with $2 n=56$, seven shared the same karyotype formulae, which was $40 \mathrm{~m}-\mathrm{sm}+16$ st-a (Table 1), and of these, six belonged to the Alto Paraná basin. This finding could indicate a more conserved karyotype evolution in these latter samples compared to the rest, probably due to chromosomal rearrangements, such as inversions and/or translocations.

According to Margarido \& Galetti Jr. (1999), heterochromatin distribution pattern allows us to establish phylogenetic relationships, in addition to being useful in the characterization and differentiation of some species. The distribution of heterochromatin in the two species followed the pattern found in the family Pimelodidae, that is, localizing in the centromeric and/or terminal regions, but showing a characteristic pattern for each species. Parapimelodus nigribarbis showed a greater quantity of heterochromatin, mainly distributed in the terminal regions. Pimelodus maculatus showed a smaller amount of heterochromatin, where this was distributed in some terminal and centromeric regions and in the interstitial portion of metacentric pair 1 .

Heterochromatin identified in the interstitial region has been observed in some samples of Pimelodus maculatus (Table 1), and in other species of the family Pimelodidae, such as Pseudoplatystoma tigrinum (Fenocchio \& Bertollo, 1992), Hemisorubim platyrhynchos (Martins-Santos et al., 1996) and Iheringichthys labrosus (Vissotto et al., 1999). These results indicate that heterochromatin at the interstitial location can be characteristic of some species of the genus Pimelodus, and some samples of $P$. maculatus. The latter heterochromatin localization can be considered an important characteristic for possible differentiation of populations and species, as well as for studies on the phylogeny of this group.

A study of Ag-NORs in Parapimelodus nigribarbis and Pimelodus maculatus indicated a pattern similar to that of other species of the family Pimelodidae, for example, in Pimelodus absconditus (Borin \& Martins-Santos, 2002), Iheringichthys labrosus (Carvalho et al., 2004) and Pimelodus fur (Garcia \& Moreira-Filho, 2005), among others. The great 
Table 1. Cytogenetic data for different samples of Pimelodus maculatus. $2 \mathrm{n}=$ diploid number; FN= fundamental number; NORs $=$ nucleolar organizer regions; $\mathrm{Hc}=$ heterochromatin; Ref. $=$ reference; $\mathrm{t}=$ terminal; $\mathrm{c}=$ centromeric; $\mathrm{i}=\mathrm{interstitial;} \mathrm{l} b=\mathrm{long}$ arm; $\mathrm{m}=$ metacentric; $\mathrm{sm}=$ submetacentric; $\mathrm{st}=$ subtelocentric; $\mathrm{a}=$ acrocentric; $*=$ FN recalculated in the present study.

\begin{tabular}{|c|c|c|c|c|c|c|}
\hline Location & $2 n$ & Karyotype formula & FN & NORs location & Hc & Ref \\
\hline $\begin{array}{l}\text { Rio São Francisco, Minas Gerais; rio } \\
\text { Mogi-Guaçu, São Paulo }\end{array}$ & 56 & $\begin{array}{c}40 \mathrm{~m} / \mathbf{s m}+\mathbf{1 6 s t} / \mathbf{a} \\
40 \mathrm{~m}, \mathrm{sm}+16 \mathrm{st}, \mathrm{a}\end{array}$ & 96 & $\mathrm{t}$, st par $23, \mathrm{lb}$ & - & Dias \& Foresti (1993) \\
\hline Rio Tibagi, Paraná & 56 & $20 \mathrm{~m}+20 \mathrm{sm}+10 \mathrm{st}+6 \mathrm{a}$ & 106 & $\mathrm{t}, \mathrm{st}$ par $23, \mathrm{lb}$ & $\mathrm{t}-\mathrm{c}$ & Swarça et al. (2001a) \\
\hline $\begin{array}{l}\text { Rio Paranapanema; Represa Jurumirim, } \\
\text { São Paulo }\end{array}$ & 56 & $20 m+20 s m+10 s t+6 a$ & $106^{*}$ & $\mathrm{t}, \mathrm{st}, \mathrm{lb}$ & $\mathrm{t}-\mathrm{c}-\mathrm{i}$ & Vissoto et al. (1999) \\
\hline Rio Paraná, Porto Rico, Paraná & 56 & $20 \mathrm{~m}+20 \mathrm{sm}+10 \mathrm{st}+6 \mathrm{a}$ & 106 & $\mathrm{t}, \mathrm{st}$ par $23, \mathrm{lb}$ & $\mathrm{t}-\mathrm{c}-\mathrm{i}$ & Borin \& Martins-Santos (2002) \\
\hline Rio Congonhas, Paraná & 56 & $20 m+20 s m+10 s t+6 a$ & 106 & st, lb & $\mathrm{t}-\mathrm{c}$ & Mazzuchelli et al. (2007) \\
\hline $\begin{array}{l}\text { Rio Mogi, rio Pardo, rio Onça,SãoPaulo } \\
\text { Rio São Francisco, Minas Gerais } \\
\text { Lago Guaíba, Rio Grande do Sul }\end{array}$ & $\begin{array}{l}56 \\
56 \\
56\end{array}$ & $\begin{array}{c}\mathbf{4 4 m} / \mathbf{s m}+\mathbf{1 2} \mathbf{s t} / \mathbf{a} \\
30 \mathrm{~m}+14 \mathrm{sm}+12 \mathrm{a} \\
32 \mathrm{~m}+12 \mathrm{sm}+12 \mathrm{st} \\
24 \mathrm{~m}+20 \mathrm{sm}+6 \mathrm{st}+6 \mathrm{a}\end{array}$ & $\begin{array}{l}100 \\
112 \\
106\end{array}$ & $\begin{array}{l}- \\
\mathrm{t}, \mathrm{sm} \text { par } 20, \mathrm{lb} \\
\mathrm{t}, \mathrm{st} \text { par } 24, \mathrm{lb}\end{array}$ & $\begin{array}{c}- \\
t-c \\
t-c-i\end{array}$ & $\begin{array}{l}\text { Toledo \& Ferrari (1976) } \\
\text { Garcia \& Moreira-Filho (2005) } \\
\text { Present study }\end{array}$ \\
\hline Rio Paraguai, Mato Grosso do Sul & 56 & $\begin{array}{c}\mathbf{3 8 m} / \mathbf{s m}+\mathbf{1 8 s t} / \mathbf{a} \\
22 \mathrm{~m}+16 \mathrm{sm}+10 \mathrm{st}+8 \mathrm{a}\end{array}$ & 104 & $\mathrm{t}, \mathrm{st}$ par $23, \mathrm{lb}$ & $\mathrm{t}-\mathrm{c}-\mathrm{i}$ & Souza et al. (2003) \\
\hline
\end{tabular}

majority of samples of P. maculatus (Table 1) possess AgNORs on st chromosomes, on the long arm, which appears to be a more conserved character in the species.

Heterochromatin associated with Ag-NORs, such as in the species studied here, has also been found in various species of pimelodids, including Iheringichthys labrosus (Vissotto et al., 1999) and Zungaro zungaro (Swarça et al., 2001b).

The presence of size heteromorphism of Ag-NORs demonstrated in Pimelodus maculatus from lago Guaíba, has also been shown in two other samples of this species, one from the rio Paranapanema (Vissotto et al., 1999) and another from the rio Paraguay (Souza et al., 2003), which could characterize some samples of $P$. maculatus. Souza et al. (2004a), utilizing an $18 \mathrm{~S}$ rDNA probe, showed that this heteromorphism was structural due to variation in ribosomal cistrons between the homologues, in the population of P. maculatus from the rio Paraguay.

The data obtained with $\mathrm{CMA}_{3}$ indicate that in both species studied here, the Ag-NORs are rich in GC pairs, where this is a general pattern found in the family Pimelodidae (Swarça et al., 2001b; Garcia \& Moreira-Filho, 2005; Swarça et al., 2005; among others). Reports of other fluorescent signals, besides those corresponding to Ag-NORs as observed in Parapimelodus nigribarbis, in the terminal region of some chromosomes, have also been identified in the family, such as in Pimelodus heraldoi and Pimelodus sp. (Souza et al., 2004b) and P. fur (Garcia \& Moreira-Filho, 2005). The combination $\mathrm{CB}+\mathrm{CMA}_{3}$ confirmed that the heterochromatin associated with Ag-NORs, in the two species, is GC-rich, while in $P$. nigribarbis, other regions were stained, which was not seen in $P$. maculatus, indicating a greater quantity of GC bases in the heterochromatin of the first species.

Staining with DAPI showed in the two species only pale regions coincident with the GC regions, thereby being DAPInegative. However, the results of $\mathrm{CB}+$ DAPI allowed the visualization of fluorescent staining on various chromosomes in both species, including the interstitial portion of chromosome 1 in Pimelodus maculatus, showing that the composition of heterochromatin includes GC bases, as noted above, and mainly AT bases, demonstrating differences between Parapimelodus nigribarbis and P. maculatus, since the first has more GC-rich heterochromatic regions.

In the sample of Pimelodus maculatus from the rio Paraguay studied by Souza et al. (2003), heterochromatin was shown to be GC-rich in the interstitial region, as seen at various telomeric regions, indicating that this population and that from lago Guaíba differ in relation to heterochromatin composition .

The karyotypic analysis of Pimelodus maculatus and of Parapimelodus nigribarbis allowed the identification of various characters common between the two genera, as well as characters common to other members of Pimelodidae, indicating conserved characters in the group. The two species, however, show differentiated characteristics in relation to the distribution pattern and composition of heterochromatin.

\section{Acknowledgments}

The authors are grateful to CAPES and Fundação Araucaria for financial support. We are also thankful to Dr. Albert Leyva for his help in the preparation of the manuscript.

\section{Literature Cited}

Bertollo, L. A. C., C. S.Takahashi \& O. Moreira-Filho. 1978. Cytotaxonomic considerations on Hoplias lacerdae (Pisces, Erythrinidae). Revista Brasileira de Genética, 1: 103-120.

Borin, L. A. \& I. C. Martins-Santos. 2002. Cytogenetic aspects in species of the genus Pimelodus (Pisces, Siluriformes, Pimelodidae) of the river Paraná Basin. Cytologia, 67:199-204.

Borin, L. A. \& I. C. Martins-Santos. 2004. Study on karyotype and occurrence of B chromosomes in two endemic species of the genus Pimelodus (Siluriformes, Pimelodidae) from the river Iguaçu. Hereditas, 140:201-209. 
Carvalho, R. A., L. Giuliano-Caetano \& A. L. Dias. 2004. Cytogenetic Analysis of A- and B-Chromosomes of Iheringichthys labrosus (Pisces, Pimelodidae) from the Tibagi River, Paraná, Brazil. Cytologia, 69: 381-385.

Della-Rosa, V. A., L. A. C. Bertollo, I. Ferrari, C. S. Takahashi, O. Moreira-Filho \& F. Foresti. 1980. Estudos citogenéticos de peixes da Amazônia. II. Ordem Siluriformes. Ciência e Cultura, 32:735.

Dias, A. L.\& F. Foresti. 1993. Cytogenetic studies on fishes of the family Pimelodidae (Siluroidei). Revista Brasileira de Genética, 16:585-600.

Fenocchio, A. S.\& L. A. C. Bertollo. 1992. Karyotipe similarites among Pimelodidae (Pisces, Siluriformes) from the Brazilian Amazon region. Cytobios, 69: p.41-46.

Ferraris Jr., C.J. 2007 Checklist of catfishes, recent and fossil (Osteichthyes: Siluriformes), and catalogue of siluriform primary types. Zootaxa, 1418: 1-628.

Garcia, C. \& O. Moreira-Filho. 2005. Cytogenetical analyses in three fish species of the genus Pimelodus (Siluriformes: Pimelodidae) from Rio São Francisco: Considerations about the karyotypical evolution in the genus. Neotropical Ichthyology, 3: 285-289.

Gil, H. R., E. Feldberg, V. M. F. Almeida-Val \& A. L. Val. 1998. Kariological, biochemical, and physiological aspects of Callophysus macropterus (Siluriformes, Pimelodidae) from the Solimões and Negro Rivers (Central Amazon). Brazilian Journal of Medical and Biological Research, 31:1449-1458.

Howell, W. M. \& D. A. Black. 1980. Controlled silver-staining of nucleolus organizer regions with a protective colloidal developer: a I-step method. Experientia, 36: 1014-1015.

Levan, A., K. Fredga \& A. A. Sandberg. 1964. Nomenclature for centromeric position on chromosomes. Hereditas, 52: 201-220.

Lucena, C. A. S. de, L. R. Malabarba \& R. E. dos Reis. 1992. Ressurrection of the neotropical pimelodid catfish Parapimelodus nigribarbis (Boulenger) with a phylogenetic diagnosis of the genus Parapimelodus (Teleostei: Siluriformes). Copeia, 1992(1): 138-146.

Margarido, V. P. \& P. M. Galetti Jr. 1999. Heterochromatin patterns and karyotype relationships within and between the genera Brycon and Salminus (Pisces, Characidae). Genetics and Molecular Biology, 22: 357-362.

Martins-Santos, I. C., H. F. Julio Jr. \& I. Burin. 1996. Karyotypic studies of four species of the Sorubiminae subfamily (Pisces, Siluriformes). Caryologia, 49: 73-80.

Mazzuchelli, J., A. C. Swarça \& A. L. Dias. 2007. Structural chromosome polymorphism in a Pimelodus maculatus La Cepède, 1803 Population (Siluriformes, Pimelodidae) from the Paranapanema River Basin, PR, Brazilian Journal of Biology, 67: 631-633
Oliveira, C.\& A. E. Gosztonyi. 2000. A cytogenetic study of Diplomystes mesembrinus (Teleostei, Siluriformes, Diplomystidae) with a discussion of chromosome evolution in siluriforms. Caryologia, 53:31-37.

Sanchez, S. 2006. Estudios citogeneticos en peces de la família Pimelodidae (Pisces, Siluriformes) de la cuenca del rio Paraná, Argentina. Unpublished Ph.D. Dissertation. Universid Nacional de Córdoba, Argentina.

Schweizer, D. 1976. Reverse fluorescent chromosome banding with chromomycin and DAPI. Chromosoma, 58:307-324.

Souza, L., L. Giuliano-Caetano \& A. L. Dias. 2003. Karyotipic Study of three species of Pimelodus (Pisces, Pimelodidae) from the Paraguai River Basin. Cytologia, 68: 345-350.

Souza, L., A. C. Swarça \& A. L. Dias. 2004a. Analysis of the nucleolus organizer regions in 5 species of the genus Pimelodus (Siluriformes, Pimelodidae) using AgNO3, CMA3 and FISH with the 18S rDNA probe. Caryologia, 57: 145-151.

Souza, L., L. Giuliano-Caetano \& A. L. Dias. 2004b. Banding chromosome pattern of two species of Pimelodus (Siluriformes, Pimelodidae) from the Paraná river basin of Brazil. Folia Biologica, Krakow, 52: p.165-169.

Sumner, A. T. 1972. A simple techinique for demonstrating centromeric heterochromatin. Experimental Cell Research, 75: 304-306.

Swarça, A. C. L. Giuliano-Caetano \& A. L. Dias. 1999. Cytogenetic caracterization through chromossomic banding of Pinirampus pirinampu (Pisces, Pimelodidae) from the Tibagi river basin PR/Brazil. Caryologia, 52:31-35.

Swarça, A. C., L. Giuliano-Caetano \& A. L. Dias. 2001a. Analyses of nucleolus organizer regions and heterochromatin of Pimelodus maculatus (Pisces, Pimelodidae). Genetica, 110: 97-100

Swarça, A. C., M. M. Cestari, L. Giuliano-Caetano \& A. L. Dias. 2001b. Cytogenetic characterization of the large south American Siluriform fish species Zungaro zungaro (Pisces, Pimelodidae). Chromosome. Science, 5: 51-55.

Swarça, A. C., A. S. Fenocchio, M. M. Cestari \& A. L. Dias. 2005. Karyotype divergence among populations of giant catfish $P$ seudoplatystoma corruscans (Pisces, Pimelodidae) indicates higher species diversity. Ichthol Expl Freshwaters 16: 325-330.

Toledo, V. \& I. Ferrari. 1976. Estudo citogenético de três espécies do gênero Pimelodus (Pimelodidae, Pisces). Científica, 4: 101106.

Vissotto, P. C., F. Foresti \& C. Oliveira. 1999. Karyotype description of five species of Pimelodidae (Teleostei, Siluriformes). Chromosome Science, 3: 1-7.

Accepted December 2007

Published 31 March 2008 